\title{
Identification of Diurnal Variation of Essential Oil Components of Hypericum perfoliatumL.(Hypericaceae)
}

\author{
Cenk PASA* and Selami SELVI
}

Balıkesir University, Altınoluk Vocational School, Departments of Plant and Animal Production, Medicinal and Aromatical Plant Programme, Altınoluk, Edremit, Balıkesir, Turkey

ISSN: 2637-7659

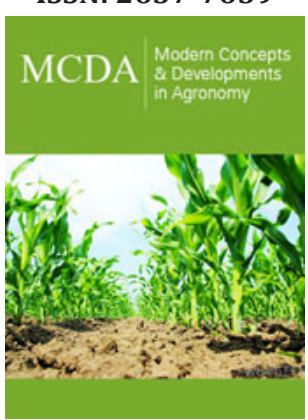

*Corresponding author: Cenk PASA, Balıkesir University, Altınoluk Vocational School, Departments of Plant and Animal Production, Medicinal and Aromatical Plant Programme, Altınoluk, Edremit, Balıkesir, Turkey

Submission: 非 August 07, 2020

Published: 眥 February 15, 2021

Volume 8 - Issue 1

How to cite this article: Cenk PASA, Selami SELVI. Identification of Diurnal Variation of Essential Oil Components of Hypericum perfoliatumL.(Hypericaceae). Mod Concep Dev Agrono. 8(1). MCDA. 000676. 2021. DOI: 10.31031/MCDA.2021.08.000676

Copyright@ Cenk PASA, This article is distributed under the terms of the Creative Commons Attribution 4.0 International License, which permits unrestricted use and redistribution provided that the original author and source are credited.

\begin{abstract}
In this study, the diurnal variability of essential oil components of the species Hypericum perfoliatum was investigated. To determine diurnal variation, during the flowering period collection was carried out at three different times of the day (9a.m., 12a.m., 4p.m.). As a result of this research, it was aimed to determine the most appropriate harvest time during the day. The essential oil components were analyzed using GC-MS device after the production of essential oil was determined by hydrodystylation method. The main components of essential oils were found to contain mainly $\alpha$-pinene (41.2\%), $\beta$-pinene (6.2\%), n-nonane (5.6\%), $\Upsilon$-muurolene (4.7\%), $\alpha$-calacorene (4.2\%), $\delta$-cadinene $(3.7 \%)$, n-undecane $(3.2 \%)$ and caryophyllene oxide (3.1\%).
\end{abstract}

Keywords: Hypericum; Diurnal;Essential oil; $\alpha$-pinene

\section{Introduction}

Turkey is an important gene center in terms of Hypericum L. (Hypericaceae) species. Hypericum genus, which is represented by approximately 500 species in the world, is represented by more than 100 taxa in Turkey, 44 of these taxa which are endemic [1]. Hypericum species have been used in the treatment of certain diseases in public medicine since the earliest times of history. In particular, Hypericum perforatum is successfully used by many countries to treat stomach ailments skin wounds, and especially antidepressants [2]. Due to these proven medicinal effects, it is a plant in most pharmacopoeia and monographs [3].

The development of these plants has reduced the use of all synthetic pharmaceutical industry, although synthetic drugs and herbal medicines to have effect dangerous side effects of a multifaceted, active compounds have stimulated studies on these plants and those obtained. However, the fact that it is difficult to collect from nature and the fact that the existence of its species is endangered makes it necessary to take these plants into culture [4].

Among the Hypericum species, hypericin and its derivatives with antifungal [5], antibacterial [6], antiviral [7] and anticancer [8] and flavonoid, floroglusinol and ksanton compounds were isolated. Hypericin and pseudohypericin are naftadiantrons with ringed structure, commonly found in Hypericum species and bearing numerous hydroxyl groups [4]. These molecules are often found in glands on the edges of leaves and petals [9].

The purpose of this research is to investigate the diurnal variability of essential oil components of the Hypericum perfoliatum species, thus determining optimal harvest times in terms of essential oil components.

\section{Material and Method}

\section{Plant samples}

Hypericum perfoliatum is a perennial herbaceous plant in the family Hypericaceae, spreading mainly in southern Europe, Cyprus and Africa.

The locality of the plant samples used in the study is given below. In addition, the geographical region where it was collected is presented in Figure 1. Turkey, B1 Balıkesir: from Balıkesir to Edremit 45km, roadsides, N: 39³3.733'; E: 27 14.902', 252m. 
During the period of full flowering plants at three different times of the day (9a.m., 12a.m. and 4p.m.) biodiversity and plant samples were taken and placed in polyethylene bags, without damaging the surface from the distribution area on labeled. The collected plant material was dried in the shade at room temperature $\left(21^{\circ} \mathrm{C}\right)$.

\section{GC-MS analysis}

The determination of essential oil components of the samples was made by Thermo Electron Trace 2000 GC Model gas chromatography and Thermo Electron DSQ Quadrupole mass spectrometer in TÜBITAK Ume Chemistry Laboratory. A homologous $n$-alkane series has been used as a reference in the calculation of Kovats indices (KI) (Table 1). The identification of the compounds was based on comparison of retention times and mass spectra with those obtained from the NIST and Wiley spectra from the original samples and from literature data [10].

Table 1: Essential oil components of $H$. perfoliatum species.

\begin{tabular}{|c|c|c|c|c|}
\hline \multirow[b]{2}{*}{$\mathbf{K I}^{*}$} & \multirow[b]{2}{*}{ Components } & \multicolumn{3}{|c|}{ Diurnal Variability } \\
\hline & & 9a.m. (\%) & 12a.m. (\%) & 4p.m. (\%) \\
\hline 900 & n-Nonane & 5.6 & 4.7 & 4.9 \\
\hline 939 & $\alpha$-Pinene & 41.2 & 38.9 & 38.1 \\
\hline 953 & Camphene & 1.2 & 2.3 & 1.6 \\
\hline 979 & $\beta$-Pinene & 6.2 & 4.2 & 3.8 \\
\hline 991 & $\beta$-Myrcene & 0.7 & 0.6 & 0.6 \\
\hline 1022 & p-Cymene & 0.5 & 0.5 & 0.4 \\
\hline 1029 & Limonene & 1.1 & 1.5 & 1.3 \\
\hline 1099 & n-Undecane & 3.2 & 2.8 & 3.8 \\
\hline 1105 & n-Nonanal & 0.6 & 0.8 & 0.6 \\
\hline 1125 & $\alpha$-Campholenal & 0.5 & 0.4 & 0.7 \\
\hline 1377 & $\alpha$-Copaene & 1.8 & 2.5 & 2.2 \\
\hline 1420 & (E)-Caryophyllene & 2.4 & 1.8 & 2.2 \\
\hline 1441 & Aromadendrene & 1.2 & 0.8 & 1.1 \\
\hline 1455 & $\alpha$-Humulene & 1.1 & 1 & 0.8 \\
\hline 1468 & allo-Aromadendrene & 2.4 & 2.1 & 2.2 \\
\hline 1481 & Ү-Muurolene & 4.7 & 5.1 & 4.1 \\
\hline 1485 & Germacrene D & 2.3 & 2.2 & 2.7 \\
\hline 1593 & Viridiflorene & 2 & 1.2 & 2.4 \\
\hline 1501 & $\alpha$-Muurolene & 1.4 & 2 & 2.2 \\
\hline 1513 & Y-Cadinene & 2.8 & 3.3 & 3.5 \\
\hline 1522 & $\delta$-Cadinene & 3.7 & 4.1 & 3.9 \\
\hline 1543 & $\alpha$-Calacorene & 4.2 & 3.8 & 4.7 \\
\hline 1578 & Spathulenol & 2.2 & 2.8 & 2.4 \\
\hline 1583 & Caryophyllene oxide & 3.1 & 3.5 & 3.3 \\
\hline 1625 & 1-epi-Cubenol & 0.6 & 0.5 & 0.5 \\
\hline 1635 & Cubenol & 0.4 & 0.6 & 0.4 \\
\hline 1657 & $\alpha$-Cadinol & 0.6 & 0.5 & 0.8 \\
\hline \multirow[t]{2}{*}{1671} & Cadalene & 0.9 & 1.1 & 0.8 \\
\hline & Total & 98.6 & 95.6 & 96 \\
\hline
\end{tabular}

*Kovats Index 


\section{Findings and Discussion}

Essential oil components of H. perfoliatum species are given in Figure 1. According to the results of essential oil components of the samples taken from the full plant at 9a.m. during the full flowering period of $H$. perfoliatum species, $\alpha$-Pinene (41.2\%), $\beta$-Pinene $(6.2 \%), n$-Nonane (5.6\%), $\Upsilon$-Muurolene $(4.7 \%), \alpha$-Calacorene (4.2\%), $\delta$-Cadinene (3.7\%), n-Undecane $(3.2 \%)$ and Caryophyllene oxide (3.1\%) were determined.

According to the results of essential oil components of the samples taken from the whole plant at noon (12:00) during the full flowering period of $H$. perfoliatum species; $\alpha$-Pinene (38.9\%), $\Upsilon$-Muurolene (5.1\%), n-Nonane (4.7\%), $\beta$-Pinene $(4.2 \%)$, $\delta$-Cadinene $(4.1 \%), \alpha$-Calacorene (3.8\%), Caryophyllene oxide (3.5\%) and n-Undecane (2.8\%) was detected. According to the results of the essential oil components of the samples taken from the whole plant in the evening (4p.m.) at the full flowering period of $H$. perfoliatum species; $\alpha$-Pinene (38.1\%), n-Nonane (4.9\%), $\alpha$-Calacorene (4.7\%), $\Upsilon$-Muurolene (4.1\%), $\delta$-Cadinene $(3.9 \%)$, $\beta$-Pinene (3.8\%), n- Undecane (3.8\%) and Caryophyllene oxide $(3.3 \%)$ was detected.

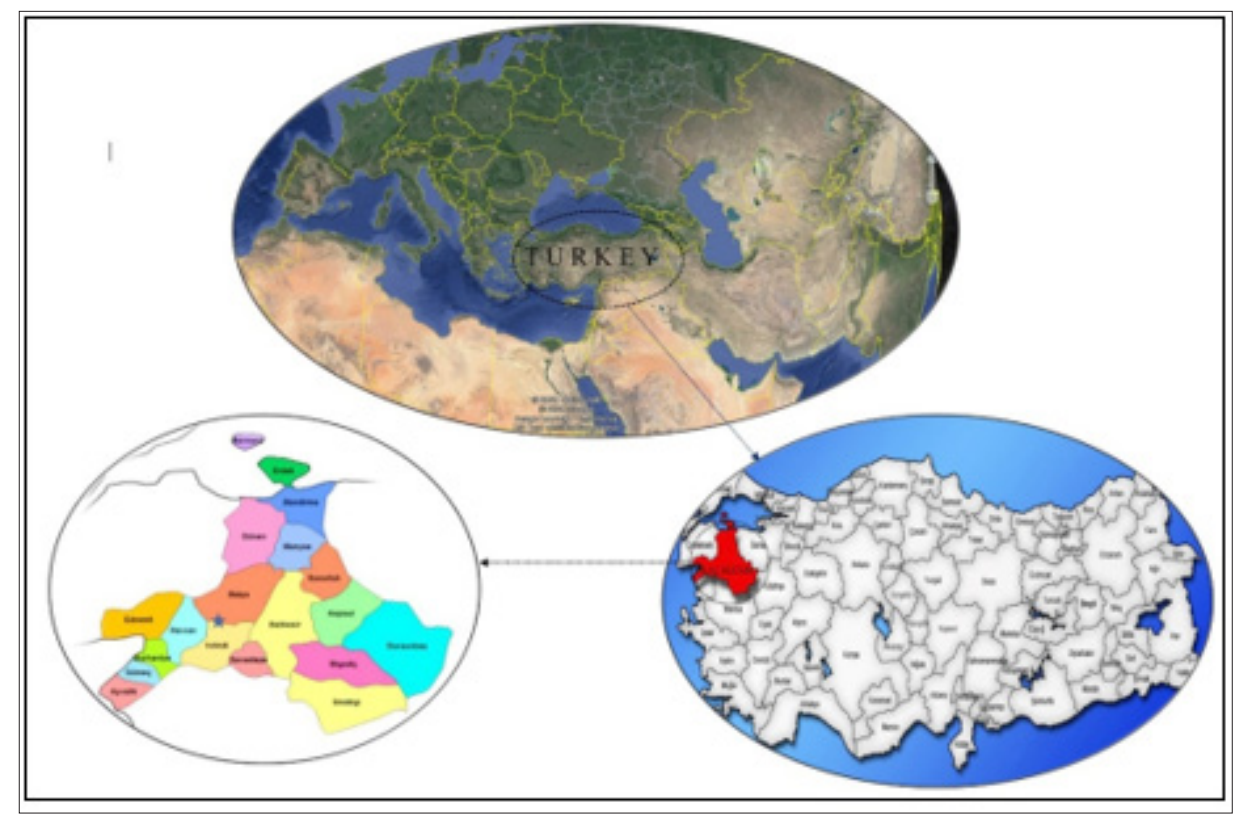

Figure 1: Geographic area where the species is collected (collected region is shown with asteriks).

As a result of the research, major components obtained from essential oil; $\alpha$-Pinene, $\beta$-Pinene and n-Nonane were determined.

In the fat Rose (Rosa damascena Mill.) in their study on determination of ontogenetic, morphogenetic and diurnal variability, they found that the ratio of essential oil decreased rapidly from morning hours to evening hours and the main component rates decreased [11]. In their study on the effect of diurnal variability on yield and quality in Thymbra capitata genotypes, found that the most appropriate collection time in terms of essential oil ratio and components was in the morning hours [12]. They determined the most suitable collection time as noon in the species Hypericum montbretii Spach [13].

The essential oil composition of Hypericum perfoliatum. As a result of their work, thirty-two compounds were identified in the essential oils of $H$. perfoliatum with -pinene $(13.1 \%)$, alloaromadendrene (11.4\%), germacrene-D (10.6\%), n-octane (7.3\%), -selinene (6.5\%) and -selinene (5.5\%) as main constituents. In our studies, pinene has been shown to be the major component [14].
Differences in research results are that the chemical composition of essential oil varies according to climatic, seasonal and geographical conditions [15].

\section{Conclusion}

In this study, the diurnal variability of the essential oil components of the $H$. perfoliatum species was determined. The highest amount of essential oil in $H$. perfoliatum was obtained from plants collected in the morning. The main components of essential oil were determined as $\alpha$-Pinene, $\beta$-Pinene and n-Nonane, and it was determined that it reached the highest values in plants collected in the morning (8a.m.).

In this study, the most appropriate collection time for the essential oil components of the species examined was determined and the most effective utilization method was determined. In addition, we believe that this study will contribute to obtaining effective results in various scientific studies, especially phytochemical and pharmaceuticals, for the collection of other Hypericum taxa to be used other than H. perfoliatum. 


\section{References}

1. Selvi S, Paşa C (2011) Türkiye florasinda bulunan hypericum (Guttiferae) türleri ve tehlike durumlari, $9^{\text {th }}$ Tarla Bitkileri Kongresi, Bursa, Turkey, pp. 1458-1461.

2. Dağdelen A, Oral RA, Selvi S, Odabaş MS (2014) A review of St. John's Wort (Hypericum perforatum L.) as medicinal and aromatic plant, American Council for Medicinally Active Plants, $5^{\text {th }}$ Annual Conference North Dakota State University, Fargo, USA.

3. Başer KHC (2009) Avrupa Farmakopesi'nin bitkisel drogları. Modern Fitofarmakoterapi ve Doğal Farmasötikler 1(1): 14-22.

4. Karakaş Ö (2010) İn vitro şartlardayetiştirilen Hypericum triquetrifolium Turra. (Guttiferae)'nın total hiperisin içeriğinin incelenmesi. Dicle Üniversitesi Fen Bilimleri Enstitüsü Biyoloji Ana Bilim Dalı, Yüksek Lisans Tezi.

5. Decosterd L, Stoeckli EH, Msonthi DJ, Hostetmann K (1986) A new antifungal chromene and a related dichromene from Hypericum revolutum. Planta Med (5): 429.

6. Ishiguro K, Yamaki M, Takagi, S (1986) Sarothralen A and B, new antibiotic compounds from Hypericum japonicum. Planta Med (4): 288290.

7. Jacobson MJ, Feinman L, Liebes L, Ostrow N, Koslowski V, et al. (2001) Pharmacokinetics, safety, and antiviral effects of hypericin, a derivative of St. John's wort plant, in patientswith chronic hepatitis C virus infections. Antimicrob Agents Chemother 45(2): 517-524.

8. Jayasuriya H, Mcchesney JD, Swason SM, Pezzuto JM (1989) Antimicrobial and cytotoxic activity of rottlerin-type compounds from hypericum drumandii. J Natural Product 52(2): 325-331.

9. Fornasiero RB, Bianchi A, Pinetti A (1998) Anatomical and ultrastructural observations in Hypericum perforatum L. leaves. J Herbs Spieces Med Plants 5(4): 21-33.

10.Sağır ZO, Çarıkçı S, Kılıç T, Gören AC (2017) Metabolic profile and biological activity of Sideritis brevibracteata $\mathrm{PH}$ Davis endemic to Turkey. Int J Food Prop 20(12): 2994-3005.

11. Baydar H, Kazaz S, Erbaș S (2013) Yağ Gülü (Rosa damascena Mill.)'nde Morfogenetik, Ontogenetik ve Diurnal Varyabiliteler. Süleyman Demirel Üniversitesi Ziraat Fakültesi Dergisi 8(1): 1-11.

12. Arabacı O, Tokul HE, Öğretmen NG, Bayram E (2015) Doğal Yayılıș Gösteren Coridothymus capitatus L. Genotiplerinde Diurnal Varyabilitenin Verim ve Kaliteye Etkisi. Ege Üniv Ziraat Fak Dergisi 52(2): 141-150.

13. Paşa C, Esendal E, Kılıç T (2018) Ontogenetic and diurnal variations of essential oil content of Hypericum montbretii Spach, cultivated in Kazdagı (Edremit/Balıkesir), Turkey. Agricultural Science and Technology 10(3): 262-265.

14. Baydar H, Sağdıç O, Özkan G, Karadoğan T (2004) Antibacterial activity and composition of essential oils from Origanum, Thymbra and Satureja species with commercial importance in Turkey. Food Control 15(3): 169-172.

15. Hosni K, Msaâda K, Ben Taârit M, Ouchikh O, Kallel M, et al. (2008) Essential oil composition of Hypericum perfoliatum L. and Hypericum tomentosum L. growing wild in Tunisia. Industrial Crops and Products 27(3): 308-314. 